\title{
Influence of Ripening and Turgor on the Tensile Properties of Pears: A Microscopic Study of Cellular and Tissue Changes
}

\author{
Nele De Belie \\ Department of Agro-engineering and Agro-economics, Katholieke Universiteit Leuven, B-3001 \\ Heverlee, Belgium \\ Ian C. Hallett ${ }^{1}$ and F. Roger Harker \\ The Horticultural and Food Research Institute of New Zealand Ltd., Private Bag 92169, Auckland, \\ New Zealand

\begin{abstract}
Josse De Baerdemaeker
Department of Agro-engineering and Agro-economics, Katholieke Universiteit Leuven, B-3001 Heverlee, Belgium
\end{abstract}

\begin{abstract}
AdDitional INDEX wORDS. european pear, Pyrus communis, asian pear, Pyrus pyrifolia, tissue failure mode
Abstract. The tensile properties of european pear (Pyrus communis L. 'Beurre Bosc') and asian pear (Pyrus pyrifolia Nakai 'Choguro') were examined using a microscope-mounted apparatus that allowed direct observation and recording of cell and tissue changes during testing. To manipulate turgor potential, tissue slices from fruit of different firmness (ripeness) were incubated in sucrose solutions of differing water potential. Solution water potentials were adjusted for individual fruit, and varied between -2.5 and $1 \mathrm{MPa}$ from the water potential of the expressed juice. Fruit firmness declined from 100 to $20 \mathrm{~N}$ and from 60 to $25 \mathrm{~N}$ during ripening of european and asian pears, respectively. For both european and asian pears the relationship between fruit firmness and tensile strength of tissue soaked in isotonic solutions was sigmoidal, with the major mechanism of tissue failure being cell wall failure and cell fracture at high firmness and intercellular debonding at low firmness. In the intermediate zone, where fruit firmness and tissue tensile strength decreased simultaneously, a mixture of cell wall rupture and intercellular debonding could be observed. Tissue and cell extension at maximum force both declined similarly as fruit softened. Tensile strength of tissue from firm pears $(>50 \mathrm{~N}$ firmness, $>0.8 \mathrm{~N}$ tensile strength) decreased by as much as $0.6 \mathrm{~N}$ during incubation in solutions that were more concentrated than the cell sap (hypertonic solutions). When similar tissue slices were incubated in solutions that were less concentrated than the cell sap (hypotonic solutions), the tensile strength increased by up to $0.4 \mathrm{~N}$. This is interpreted as stress-hardening of the cell wall in response to an increase in cell turgor. Tensile strength of tissue from soft pears was not affected by osmotic changes, as the mechanism of tissue failure is cell-to-cell debonding rather than cell wall failure.
\end{abstract}

The strength of an edible fruit tissue is a function of the mechanical properties of the cell wall, cell properties such as turgor, and bonding between neighboring cells (Harker et al., 1997a). The relative importance of strengths of the primary cell wall and middle lamella has been studied using tensile tests and observations of fracture surfaces (Harker and Hallett, 1992, 1994; Harker and Sutherland, 1993; Harker et al., 1997b). During fruit ripening, hydrolysis of middle lamella pectins results in tissues failing by cell-to-cell debonding rather than cell rupture (Harker et al., 1997a). Thus, in many soft fruit tissues it is the weakness of cell-to-cell bonding that determines tissue failure, and the strength of the primary cell wall is of relatively little importance.

Another important factor that contributes to the strength of fruit tissues is the contents of the cell. When subjected to compressive forces, cell strength is basically a hydrostatic phenomena, and the cell wall has little load bearing capacity in the absence of cell contents (Harker et al., 1997a). Furthermore, cell turgor

Received for publication 19 Oct. 1998. Accepted for publication 5 Feb. 2000 N.M. De Belie is a Postdoctoral fellow of the Fund for Scientific ResearchFlanders (FWO) and wishes to thank the FWO for the mobility grant that enabled her to carry out this research at the Horticulture and Food Research Institute of New Zealand. We also thank the New Zealand Foundation for Research Science and Technology for funding this study. The cost of publishing this paper was defrayed in part by the payment of page charges. Under postal regulations, this paper therefore must be hereby marked advertisement solely to indicate this fact. ${ }^{1}$ To whom reprint requests should be addressed; email ihallett@hort.cri.nz. (internal pressure) is thought to have a major influence on the strength of tissues (Falk et al., 1958; Jackman et al., 1992; Lin and Pitt, 1986; Nilsson et al., 1958; Steudle and Wieneke, 1985). While there are few actual measurements of turgor in fruit cells (Shackel et al., 1991), turgor can be manipulated by incubating excised fruit discs in solutions that vary in water potential. Changes in water relations that occur during incubation are indicated by changes in disc weight and volume (Harker and Hallett, 1992, 1994; Harker and Sutherland, 1993; Jackman et al., 1992; Lin and Pitt, 1986). It is generally assumed that turgor develops when discs are incubated in solutions that have a higher water potential (closer to pure water) than the cell sap. In some cases water uptake results in cell damage as indicated by increased leakage of electrolytes (Simon 1977), loss of disc weight (Harker and Hallett, 1992, 1994; Harker and Sutherland, 1993), and gross loss of tissue strength (Lin and Pitt 1986).

Studies with apple [Malus sylvestris (L.) Mill. var. domestica (Borkh) Mansf.] and tomato (Lycopersicon esculentum Mill.) fruit have demonstrated that tissue failure occurs at lower compression forces when cell turgor is increased (Jackman et al., 1992; Lin and Pitt, 1986). This is often interpreted as higher turgidity prestressing the cells and making them more brittle (Pitt and Chen, 1983). Studies using pressure probes have indicated that the cell wall elastic modulus increases with turgor in apple cells (Steudle and Wieneke, 1985) suggesting that the cell walls become stress-hardened as turgor increases. Falk et al. (1958) and 
Nilsson et al. (1958) also demonstrated that elastic modulus of parenchymatous plant tissues increases with the turgor potential. De Baerdemaeker et al. (1978) found that water potential affects tensile and compressive strength of apple tissue. A decrease in tensile stress at failure was observed with decreasing water potential while at the same time compressive strength increased.

Clearly, the interactions between cell wall strength, cell-to-cell bonding, and turgor are complex. To explore the complexity of these interactions we have recently developed an approach in which thin strips of tissue were pulled apart under a microscope so that deformation could be examined at the cellular level (Hallett and Harker, 1998). In this study we have further developed the method to allow force deformation characteristics of tissue slices to be related to the mode of tissue failure, and to the deformation of individual cells. We have used this technique to study the influences of cell turgor and fruit ripening on tissue and cellular characteristics.

\section{Materials and Methods}

European (Pyrus communis 'Beurre Bosc') and asian (Pyrus pyrifolia 'Choguro') pears were harvested at commercial maturity in Hawkes Bay, New Zealand and placed in cold storage at 0 to $1^{\circ} \mathrm{C}$. Fruit were stored between 4 and 10 weeks before removal and were allowed to warm to $20^{\circ} \mathrm{C}$ before being tested. European pears were tested upon removal from storage, and after ripening for between 2 and $10 \mathrm{~d}$ at $20^{\circ} \mathrm{C}$. Asian pears were also examined on removal and after various periods up to $13 \mathrm{~d}$ at $20^{\circ} \mathrm{C}$.

The firmness of each pear was determined by penetrometer measurements using a materials testing machine (model 4301; Instron, Canton, Mass.) with an Effegi probe of $8 \mathrm{~mm}$ diameter and a speed of $240 \mathrm{~mm} \cdot \mathrm{min}^{-1}$. The water potential of the juice from each pear was measured using a vapor pressure osmometer (Wescor 5500; Logan, Utah). Tissue blocks of constant width were cut using two parallel razor blades separated by a distance of $8 \mathrm{~mm}$. Tissue slices of $600 \mathrm{~mm}$ thickness were cut from these blocks with a vibratome (Vibratome 1000; Technical Products International, St Louis, Mo.). Slices were cut in a sucrose solution that had the same water potential as pear juice to reduce osmotic shock and prevent dehydration. The slices were then transferred to petri dishes containing $\approx 15 \mathrm{~mL}$ of sucrose solution that varied in water potential (tissue slices represented $\approx 1 \%$ of solution volume). The differences between the water potential of the pear juice and the water potential of the sucrose solutions $(\Delta \psi)$ were $\approx 0.8,0.4,0,-0.4,-1.3$, and $-2.3 \mathrm{MPa}$ for european pear, and $\approx 0.5$, $0,-0.4$, and $-1.5 \mathrm{MPa}$ for asian pear. Solution water potentials needed to be adjusted for each individual pear due to fruit-to-fruit differences in water potential of expressed juice. The slices were held in these various solutions for between 30 and $180 \mathrm{~min}$. This 2.5-h period corresponded with the time it took to make 20 tensile measurements (five slices of tissue in each of four incubation solutions from a single pear). To improve both the contacts between cells and the osmoticum, and visualization of cells through the microscope, gas in intercellular spaces was removed by vacuum infiltration ( 3 to $5 \mathrm{~min}$ aspiration in a vacuum desiccator). A preliminary series of experiments indicated the method described above did not damage the cells or alter the mechanical properties of the tissue.

For each pear tested, five tissue slices were placed into each osmotic solution. The slices were vacuum infiltrated and incubated in the osmotic solution for at least $30 \mathrm{~min}$ before testing. We selected the tissue slices for tensile testing in a systematic manner, one slice from each solution in turn. Data points are presented as the means of those five repetitions unless otherwise mentioned. Data were analysed using analysis of variance (SPSS 7.5; SPSS Inc., Chicago, Ill.) and chi square (Origin 5.0; Microcal Software Inc, Northampton Mass.) as appropriate.

Tensile testing was performed on a microscope slide modified to allow the tissue slice to be pulled apart while viewing under a microscope (Fig. 1). Two thin aluminum guides acted both as spacers between the slide and coverslip and as guides for the tissue support plates, allowing these to be located repeatedly in the same starting position. For examination, the tissue slice was blotted to remove excess surface moisture and glued with a cyanoacrylate adhesive (Selleys, Padstow, Australia) to the two aluminum tissue support plates. After the glue had dried $(\approx 15 \mathrm{~s})$, a coverslip was applied and the chamber was flooded with the appropriate osmotic solution. The slide was mounted on the microscope stage and one of the tissue support plates was pulled away from the other at a rate of $3 \mathrm{~mm} \cdot \mathrm{min}^{-1}$ using a materials testing machine (model MN44; Instron, Canton, Mass.) that had been placed on its side alongside the microscope. The force displacement curves were recorded and used to identify the maximum force (tensile strength) and extension at failure.

Cell changes during extension and the mode of tissue failure were observed by light microscopy, and the sequence from resting to fracture was recorded onto videotape, using a color CCD camera (model KY-F30B; JVC, Tokyo, Japan). Individual frames of resting tissue and tissue just prior to breaking were transferred to a computer using a video capture card (Video
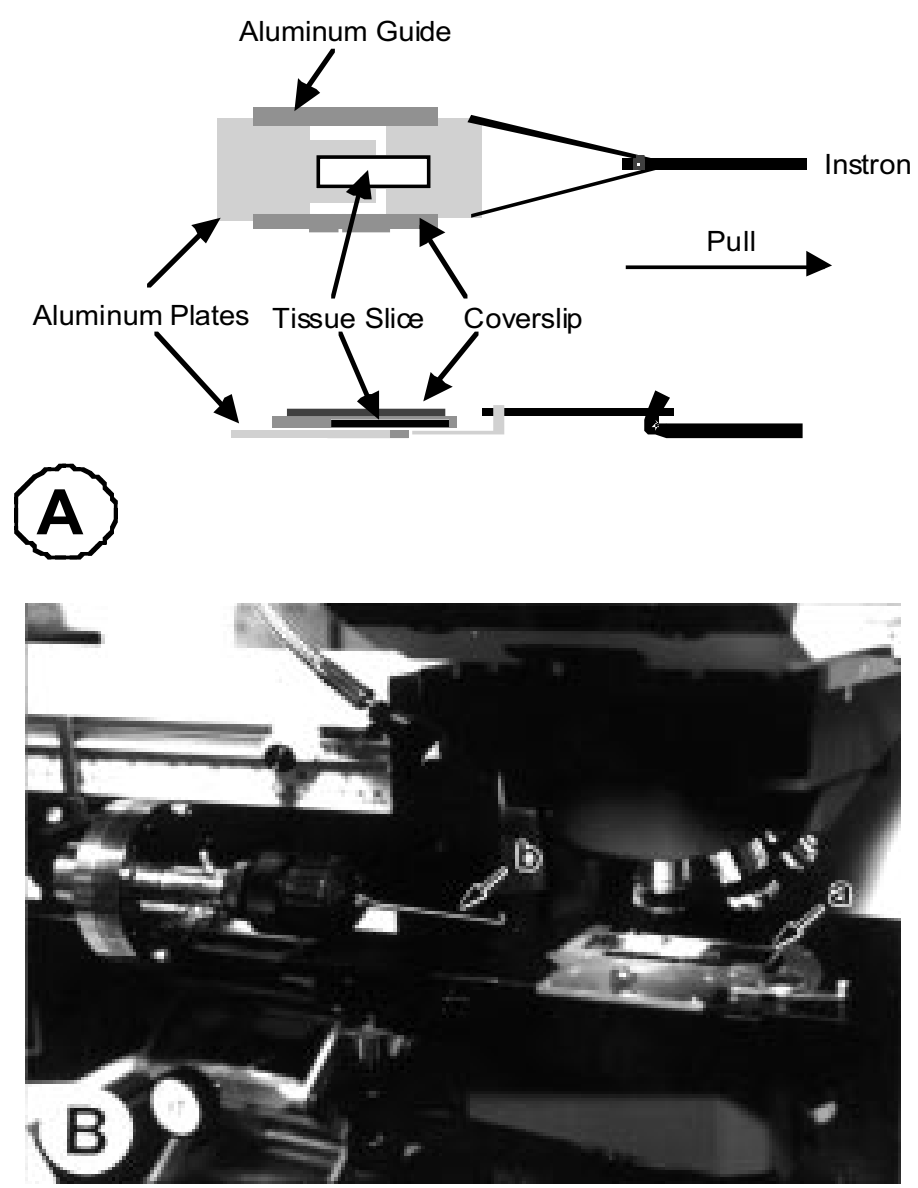

Fig. 1. (A) Schematic view of slide mounted system used to pull fruit tissue slices apart. (B) Experimental system with slide (a) installed on microscope stage and attached by hook (b) to Instron load cell. 
European Pear
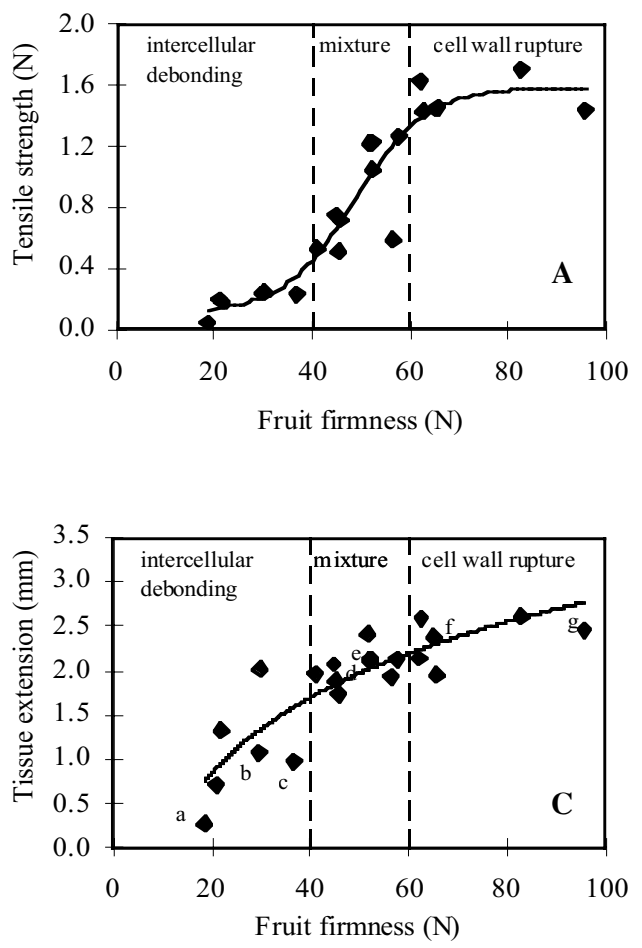

Asian Pear
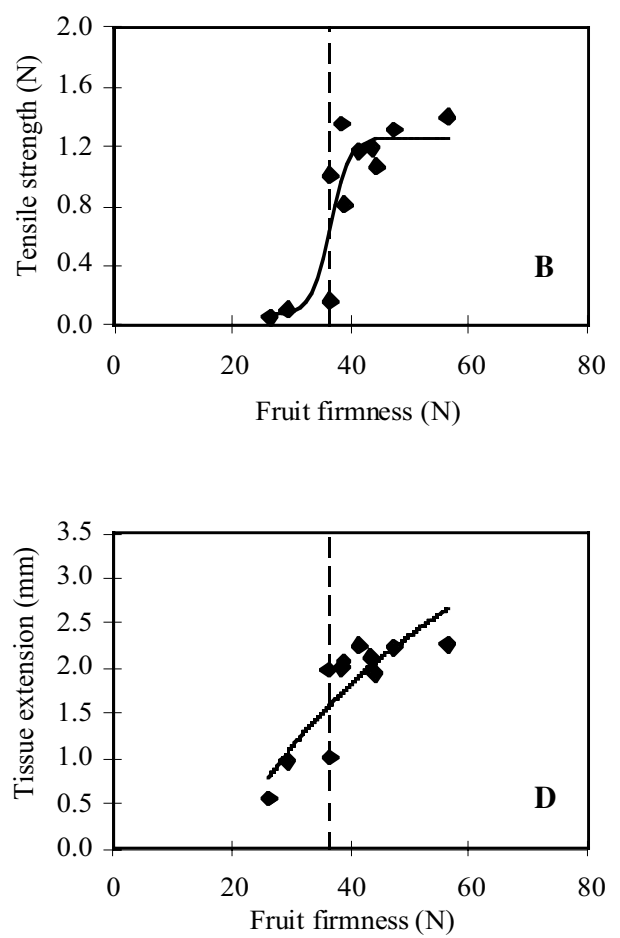

\section{Results}

Preliminary investigations. Visual examination by an experienced microscopist (I.C. Hallett) indicated that infiltration with the solution of the highest water potential (closest to pure water) did not damage cells. The cells were intact, turgid, with no internal collapse. Incubation in solutions that were more concentrated than the cell contents (expressed juice) resulted in an increasing number of plasmolysed cells. However, even when the water potential of the incubating solution was the same as the cell contents, a small number of individual cells showed limited plasmolysis. This observation suggests the osmotic potential was not uniform from cell to cell.

Vacuum infiltration caused no change in the tensile strength of pear tissue infiltrated with solutions of the same water potential as the juice. At higher concentrations of sucrose, both infiltrated and noninfiltrated samples showed similar reductions in tensile strength. Following these initial changes, tensile strength remained stable within the experimental period of 30 to $180 \mathrm{~min}$ after vacuum infiltration.

Fruit firmness, tissue WAter potential, and tensile STRENGTH. On removal from cool storage, european pears ranged
Fig. 2. Relationships between fruit firmness (A and $\mathbf{B})$ and the tensile strength and (C and D) extension at maximum force of slices of pear tissue. Tissue slices were excised from (A and $\mathbf{C}$ ) european and (B and $\mathbf{D})$ asian pears, and were incubated in sucrose solutions that were the same water potential as the juice expressed from each fruit. Chi square of fitted curves were (A) 0.037 and (B) $0.089 ; r$ of fitted exponential curves was (C) 0.87 and (D) 0.85 . Each symbol represents the mean of five slices from each pear; and lower case letters in $\mathbf{C}$ correspond to fruit used for cellular strain measurements (Fig. 7).

Blaster RT300; Creative Labs Inc, Milpitas, Calif.) and saved as bitmap files. Measurements were performed using image processing software (Optimas v 5.2; Media Cybernetics, Silver Spring, Md.). The dimensions parallel and orthogonal to the direction of the applied force were measured for the same five individual cells in resting tissue, and just prior to tissue breaking. These measurements were used to calculate the cell strain (increase in length divided by original length) just before the tissue broke.

Fig. 3. Effect of incubation in hypertonic and hypotonic solutions on (A and $\mathbf{B}$ ) tensile strength and $(\mathbf{C}$ and $\mathbf{D})$ tissue extension at maximum force of tissue slices from (A and $\mathbf{C}$ ) european pears and $(\mathbf{B}$ and $\mathbf{D})$ asian pears. Chi square of fitted exponential decay were (B) 0.0244 and (B) 0.0054. Difference in water potential $(\Delta \psi)$ was determined for individual pears by subtracting the water potential of the incubation solution from the water potential of the expressed juice. Each symbol in (A) and (B) represents the mean of five slices from each pear. Data points in $(\mathbf{C})$ and $(\mathbf{D})$ represent averages calculated for all pears at each $\Delta \psi$.
European Pear
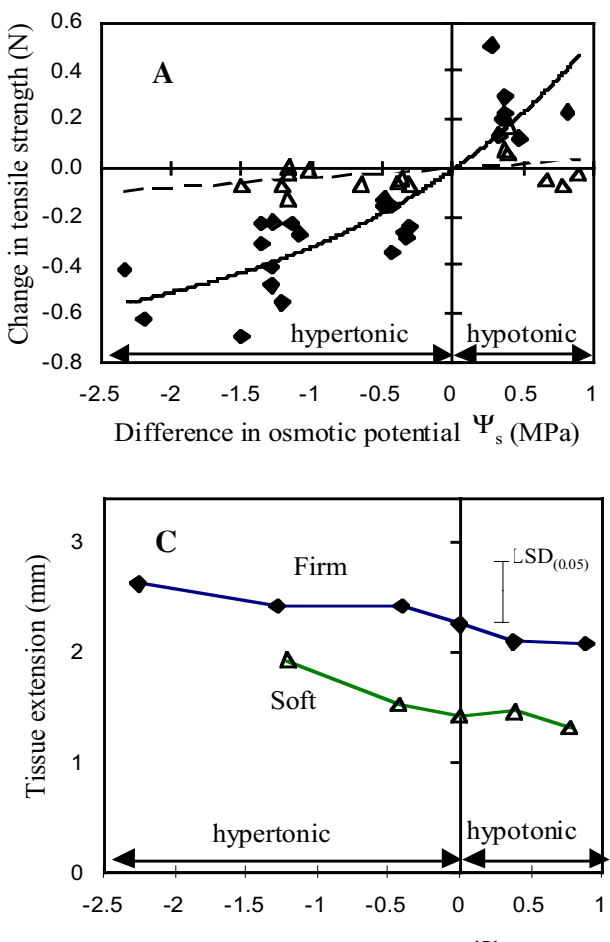

Difference in osmotic potential $\Psi_{\mathrm{s}}(\mathrm{MPa})$
Asian Pear
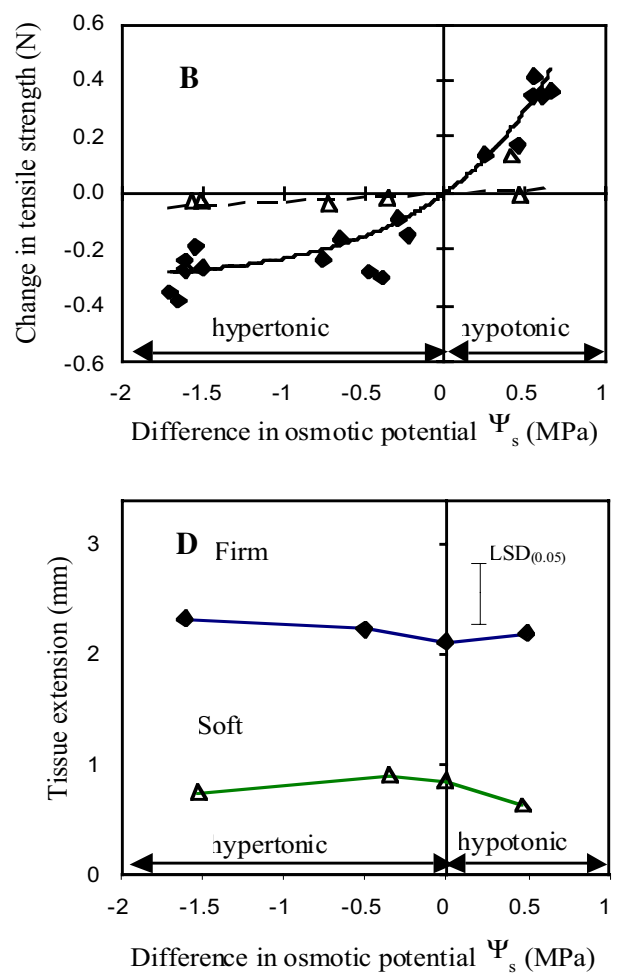


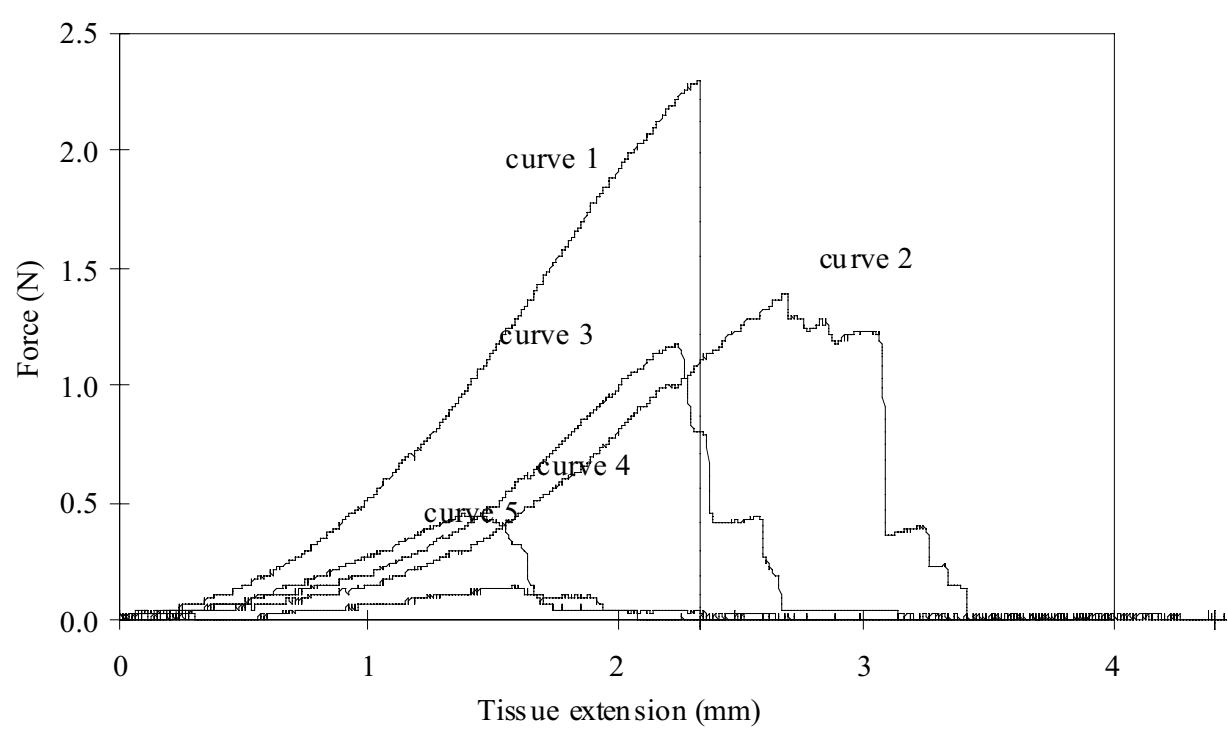

associated study using scanning electron microscopy (I.C. Hallett, unpublished data).

INFLUENCE OF TURGOR POTENTIAL. Turgor is often calculated according to $\psi$ $=\mathrm{P}-\pi$, where $\psi$ is the water potential of the tissue, $\mathrm{P}$ is the turgor potential, and $\pi$ is the osmotic potential of the cell contents (Dainty 1976). However, we did not feel this was appropriate for fruit cells, since Shackel et al. (1991) found that turgor, as measured using a pressure probe, was not what they expected based on osmotic potentials of sap extracted from freeze-thawed pericarp discs. In the present study, we assume that turgor is being manipulated, but recognize that there are pitfalls with any simple interpretation. For this reason we use the symbol $\Delta \psi$ (the difference between the water potential of juice extracted from
Fig. 4. Representative force-displacement curves of tensile tests on pear tissue.

in firmness between 96 and $62 \mathrm{~N}$. After subsequent ripening at 20 ${ }^{\circ} \mathrm{C}$, firmness dropped progressively to $18 \mathrm{~N}$. Firmness of asian pears ranged from 56 to $26 \mathrm{~N}$, with softer fruit only occurring after 12 to $13 \mathrm{~d}$ ripening at $20^{\circ} \mathrm{C}$. The average water potential of the expressed juice of the european pears (range $=-1.64$ to -2.19 $\mathrm{MPa}$, average $=-2.00 \mathrm{MPa}$ ) was lower than the water potential of the asian pears (range $=-1.50$ to $-1.84 \mathrm{MPa}$, average $=-1.67$ $\mathrm{MPa})$. For both groups the water potential was not influenced by fruit softening indicating that most starch had been converted to sugars prior to the start of experimentation.

The relationship between fruit firmness and tensile strength was examined for tissue slices incubated in solutions that were isotonic with the juice expressed from each fruit. For both european and asian pears the relationship was curvilinear rather than linear, and different regions could be distinguished (Fig. 2A and B). Unripe european pears showed a tissue tensile strength of $\approx 1.5 \mathrm{~N}$, regardless of fruit firmness $(60$ to $95 \mathrm{~N})$. When ripened at $20{ }^{\circ} \mathrm{C}$, fruit firmness and tissue tensile strength dropped simultaneously until fruit firmness reached a value of $\approx 40 \mathrm{~N}$. For ripe european pears with a firmness of 20 to $40 \mathrm{~N}$, the tissue tensile strength again varied little and was $\approx 0.2 \mathrm{~N}$. The three regions described above could also be distinguished for asian pears, but the decrease in tissue tensile strength in the intermediate region was much more abrupt. Asian pears with low tissue tensile strength $(<0.2 \mathrm{~N})$ clearly lacked the desirable textural properties of the fruit (crispness) and could be best termed overripe (sensory evaluation by N. De Belie). In this study, pears of high tensile strength and firmness (unripe european pear and most asian pears) are termed firm fruit whereas pears with low tensile strength and firmness (ripe european pear and overripe asian pears) are termed as soft fruit.

The three regions of the firmness/tensile strength curves also corresponded to different modes of tissue failure. For the pears of high firmness and tissue tensile strength, tissue failure was due to cell wall failure and cell fracture. Pears of low firmness and tensile strength clearly showed cell-to-cell debonding. In the intermediate zone, a mixture of cell wall rupture and cell-to-cell debonding could be seen. These findings were confirmed in an
Table 1. Percentage of tissue samples that fractured abruptly during tensile tests (e.g., force-displacement curve shape 1 in Fig. 4). The data represent testing of tissue from european pears of different firmness incubated in hypertonic, isotonic, and hypertonic solutions. Values in bracket represent the total number of observations.

\begin{tabular}{lccc}
\hline \hline & \multicolumn{3}{c}{ Incubation solution } \\
\cline { 2 - 4 } Pear firmness $(\mathrm{N})$ & Hypotonic & Isotonic & Hypertonic \\
\hline Firm $(>60)$ & $77(30)$ & $43(30)$ & $25(60)$ \\
Intermediate $(40-60)$ & $53(30)$ & $29(45)$ & $4(50)$ \\
Soft $(<40)$ & $20(15)$ & $21(29)$ & $10(30)$ \\
\hline
\end{tabular}

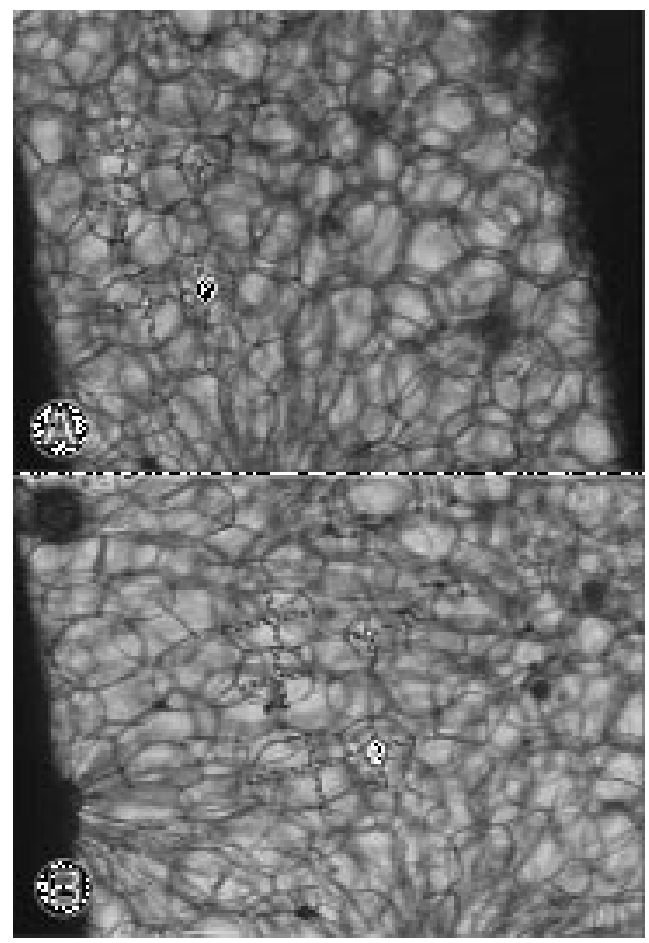

Fig. 5. Photomigrographs as examples of cell strain measurement for european pear of intermediate firmness. (A) cell dimensions in resting tissue, and (B) just before tissue breaking. Dark spots indicate reference cell. 


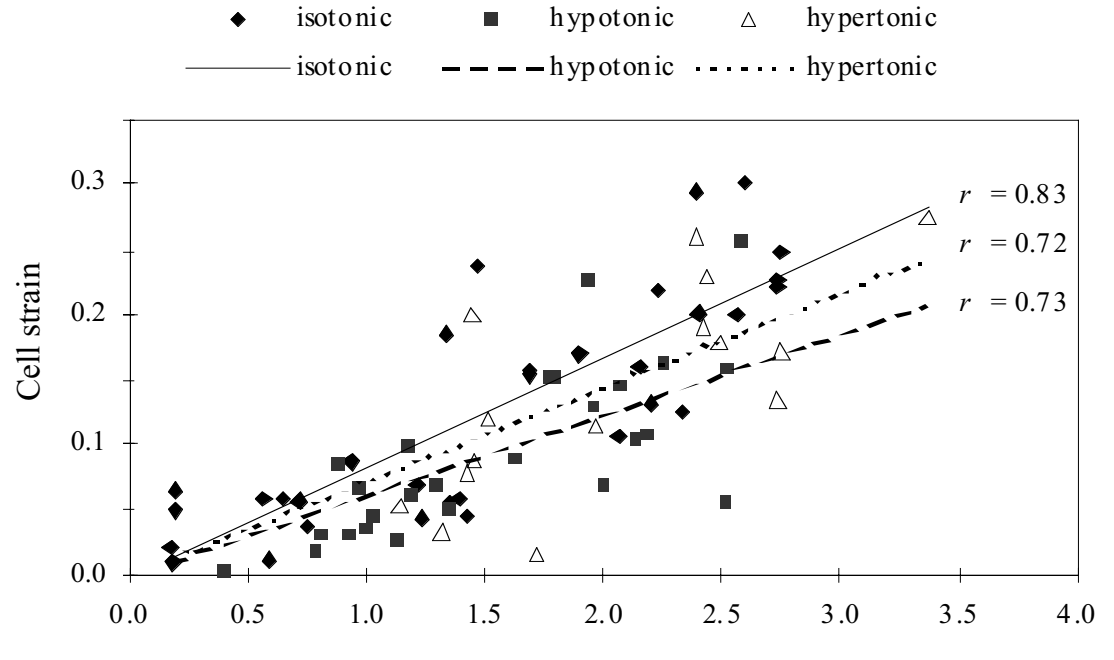

Tiss ue extens ion ( $\mathrm{mm})$

Fig. 6. Cell strain compared with tissue extension for seven european pears. Cell strain is the average dimensional change of five cells from each slice.

the tissue and the water potential of the incubation solution) to emphasize that we are calculating rather than measuring turgor (Fig 3). The terms hypotonic, isotonic, and hypertonic are used to indicate when the incubation solution has respectively a higher (less negative), the same, or a lower (more negative) water potential than the expressed juice.

The change in tissue tensile strength due to submersion in a nonisotonic solution from the average tissue strength of the same pear stored in an isotonic solution is illustrated in Fig. 3A and B. In european pear, fruit could be separated into two groups based on fruit firmness. For pears with a firmness higher than $50 \mathrm{~N}$ (firm), a clear influence of the water potential of the incubation solution could be found, while this had no effect on pears of lower firmness (soft). The arbitrary limit of $50 \mathrm{~N}$ corresponded more or less with the bending point of the S-curve in Fig. 2A. Similarly, in asian pears, fruit of low tensile strength (soft) was unaffected by differences in water potential.

For firm european and asian pears, incubation in hypotonic solutions $(\Delta \psi=0$ to $1 \mathrm{MPa})$ caused an increase in tensile strength. Submersion in hypertonic solutions $(\Delta \psi=-2.5$ to $0 \mathrm{MPa})$ caused a decrease in tensile strength. For soft european and asian pears, no such correlation could be found.

For firm european and asian pears, the effect of solution water potential (i.e., $\Delta \psi$ groups of $\approx 0.8,0.4,0,-0.4,-1.3$, and -2.3 $\mathrm{MPa})$ on absolute values of tensile strength was significant $(P=$ 0.05) (note: in Fig. 3 relative values of tensile strength are presented). There was no significant difference for soft pears.

FORCE-DISPLACEMENT CURVES. Fruit ripeness and turgor potential had an influence on the shape of the force-displacement curves (Fig. 4). In most examples there was a steady increase up to a maximum force. Tissue could break abruptly, as indicated by the sharp peak of curve 1, or alternatively different cells or cell groups could rupture sequentially, which would result in a curve shaped like curve 2 or 3 . Curves of shape 1 were predominant for tissue slices from firm pears incubated in hypotonic solutions $(\Delta \psi$ $=0$ to $1 \mathrm{MPa}$; Table 1 ), whereas curves of shape 2 and 3 corresponded to softer pears and/or isotonic $(\Delta \psi=0 \mathrm{MPa})$ and hypertonic $(\Delta \psi=-2.5$ to $0 \mathrm{MPa})$ solutions. Curve shapes 4 and 5 were characteristic of very soft ripe and overripe pears.

Tissue EXTension. From the force-displacement curves, the tissue extension at maximum force could be calculated. The relationship between the average extension of pear tissue slices and the pear firmness is illustrated in Fig. 2C and D. The influence of solution water potential on tissue extension of firm and soft pears is shown in Fig. 3C and D. Tissue extension decreased significantly upon softening for all solution water potentials. For european pears there was a clear increase in extension as $\Delta \psi$ was lowered $(P=0.05$; Fig. $3 \mathrm{C})$. However, there was no significant influence of $\Delta \psi$ on extension of tissue excised from asian pear.

EXTENSION OF INDIVIDUAL CELLS. Examples of changes in cell dimensions during extension are shown in Fig. 5, while Fig. 6 presents the average cell strain (a dimensionless proportion representing change in length/original length) versus the tissue extension for tissues from seven pears in solutions of different water potential. Tissue data are presented as extensions because variations in the point of attachment (by gluing) between the tissue slices and support plates may have resulted in differences in the length of the pulled tissue making a strain calculation unreliable.

Correlation between average cell strain and tissue extension was good and may have been improved further by measuring more than five cells per tissue. The relationship between cell strain and firmness (Fig. 7) is similar to that between tissue extension and firmness (Fig. 2C). However, there was considerable variation in strain experienced by cells from the same tissue (Fig. 7) an observation that is also true for cells within the same tissue slice (data not presented). The area of the profiles of the measured cells was estimated by the area of an ellipse with the cell length and cell width as axes. When the tissue was pulled, this area appeared to increase significantly. Since water can only be compressed to a limited extent, an increase in cross-sectional area could only have occurred if there was a significant reduction in height of the cells (possibly because cell distortion in the vertical dimension is less restricted by the presence of other cell layers). Unfortunately, cell volume changes could not be assessed, as the cell depth could not be measured.

\section{Discussion}

The methodology described herein is unique since it allowed us to view cell changes during the deformation of living tissue.

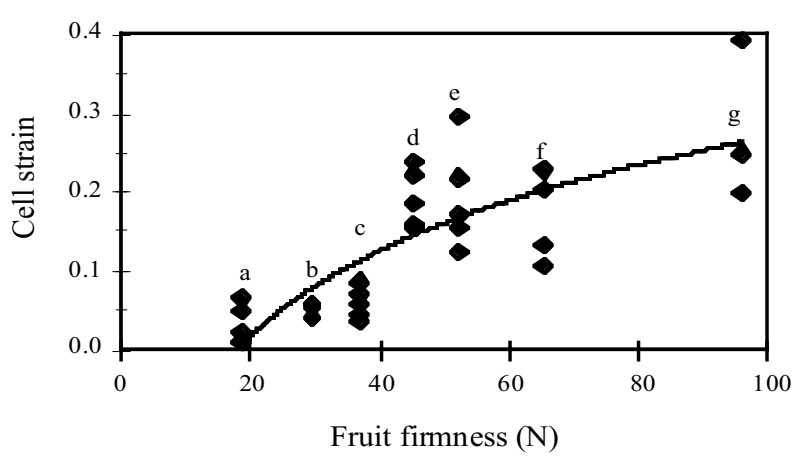

Fig. 7. Relationship between cell strain and firmness with european pears; $r$ of fitted curve $=0.80$. Each symbol represents the mean of five cells, and lower case letters correspond to the same fruit in Fig. 2C. 
Video images showed dramatic differences in the failure of tissue from soft and firm pears. Representative video sequences are available from the corresponding author upon request. These differences were assessed qualitatively/quantitatively according to the mechanism of cell failure (Fig. 2) and the change in cell length and width (Figs. 5, 6, and 7). Earlier tests have characterized mechanical properties of tissue according to force-deformation curves and by examining fracture surfaces after tissue failure (e.g., Diehl et al., 1979; Harker et al., 1997b; Peleg et al., 1976). Dynamic tests (Jackman and Stanley, 1992) and stress-relaxation tests (Sakurai and Nevins, 1993) allow tissue strength to be interpreted in terms of elastic, plastic, and viscoelastic properties of the tissue, but do not allow visualization of cell changes.

There was a curvilinear relationship between fruit firmness and the tensile strength of cells, with a clear upper threshold (Fig. 2 ). The upper threshold was unexpected, since tissues generally exhibit a linear increase in tensile strength with increasing firmness (Harker et al., 1997b). This probably represents the differences in mechanical properties of a population of cells versus individual cells. In a puncture test on whole fruit, the compression and shear properties of the tissue (cell population) are being determined (Bourne, 1975; Harker et al., 1997a). Conversely, during tensile testing of thin layers of cells, it is the strength of the weakest cell that may define the strength of the entire sample. Thus, the upper threshold in Fig. 2A suggests that the tensile strength of the weakest cells did not change even though fruit firmness varied between 60 and 90 N. However, we speculate that the tensile strength of the average cell may be greater with greater firmness. The lower threshold (Fig. 2A) probably indicates that cell-to-cell adhesion as tested at a speed of $3 \mathrm{~mm} \cdot \mathrm{min}^{-1}$ has reached a lower limit.

Cell turgor did not affect tensile strength of soft tissues (Fig. $3 \mathrm{~A}$ and $\mathrm{B}$ ) since failure was due to cell-to-cell debonding at the middle lamella. In firm pears, tissue failure was associated with breaking of primary cell wall, and resulted in rupturing of individual cells (Fig. 2A and B). Here, cell turgor had a profound influence on the tensile strength of pear tissue (Fig. 3A and B). Tissue slices incubated in hypotonic solutions $(\Delta \psi=0$ to $1 \mathrm{MPa})$ broke at higher tensile loads than tissues incubated in either hypertonic solutions $(\Delta \psi=-2.5$ to $0 \mathrm{MPa})$ or isotonic solutions $(\Delta \psi=0 \mathrm{MPa})$. Thus, cell turgor that presumably developed in slices incubated in hypotonic solutions $(\Delta \psi=0$ to $1 \mathrm{MPa})$ tended to stress-harden the fruit cell walls of the genus Pyrus L. The observation that tissue failure occurred at higher forces when slices were incubated in hypotonic solutions differs from observations made in studies using uniaxial compression of apple and tomato discs (Jackman et al., 1992; Lin and Pitt, 1986). Studies using uniaxial compression of fruit discs show that tissues incubated in hypotonic solutions fail at a lower force than those incubated in isotonic or hypertonic solutions. This phenomenon is usually interpreted in terms of turgor prestressing the cell wall and making it more brittle (Pitt and Chen, 1983). Steudle and Wieneke (1985) found that an increase in pressure tended to stress-harden the cell wall, but they did not examine cell failure or tissue rupture.

Not only did our study demonstrate that turgor hardened the tissue rather than enhancing brittleness, but we also found that the pattern of cell failure (e.g., cell-to-cell debonding and/or cell breakage) differed from those described in earlier studies. In the present study, the mode of cell failure was not dependent on turgor potential, but only on ripeness. This is contrary to results obtained using compressive tests (Lin and Pitt, 1986) which showed that cell debonding and cell wall rupture were the dominant failure mechanisms at low and high turgor potentials, respectively.

The use of tensile or compressive tests clearly has a profound influence on the type of results obtained during studies on the influence of turgor on tissue failure. Generally, failure in uniaxial compression may represent the rupturing of cell walls as a result of extreme shear stresses that develop during the testing of unripe tissue (Diehl et al., 1979; Peleg et al., 1976). Diehl et al. (1979) consider that increased turgor associated with volume change during compression tests contributes to the shearing of cells. By comparison, failure during tensile testing involves tearing of the cell wall and/or cell-to-cell debonding (Harker et al., 1997a). From an applied perspective, studies using compression tests may be relevant to understanding factors affecting development of bruises, while results from tensile studies are more closely related to biting and chewing of food (Harker et al., 1998, 1997a).

Changes in tissue strength associated with manipulation of cell turgor are usually characterized by incubating tissue in different osmotic solutions (e.g., the present study as well as Jackman et al., 1992 and Lin and Pitt, 1986). It is generally assumed that turgor will change according to classical water relations theory (Dainty, 1976). However, no study has confirmed these changes by measuring turgor, e.g., by using a pressure probe. Furthermore, there has been little consideration of how turgor that has been artificially elevated in vitro relates to the turgor experienced within the fruit. Shackel et al. (1991) found that the highest turgors in tomato fruit cells were $<0.2 \mathrm{MPa}$, probably indicating the presence of high concentrations of apoplastic solutes. It is possible that turgor that develops in cells during normal fruit growth never reaches the values that they are subjected to during in vitro studies. Thus, the role of turgor in determining tissue strength remains ambiguous.

The cells were able to withstand incubation in solutions as low as half the water potential of the juice expressed from each fruit (hypotonic solutions). Under these conditions the cells did not exhibit any obvious visible or physical signs of cell damage, and furthermore tissue strength was greater than that of slices incubated in isotonic and/or hypertonic solutions $(\Delta \psi=-2.5$ to $0 \mathrm{MPa}$; Fig $3 \mathrm{~A}$ ). This suggests that pear cells are similar to strawberry (Fragaria xananassa Duchesne) cells (Pomper and Breen, 1996) in their ability to withstand incubation in solutions with high water potential. A number of mechanical models have been developed to explain the influence of individual cells on the rheological properties of fruit tissues (e.g., Nilsson et al., 1958; Pitt, 1982; Pitt and Chen, 1983) and interest in this approach continues (Pitts et al., 1993; Wu and Pitts, 1999). These models assume that a tissue is composed of a population of identical cells which bear approximately the same load and undergo the same strain (e.g., Pitt and Chen, 1983). However few, if any, of these assumptions have been tested.

Several of the observations made in the present study may be relevant to models described above. Turgor seems to have no impact on the tensile strength of soft fruit where tissue failure is due to cellto-cell debonding. Cell responses to tensile tests were different from those described in the literature for compressive testing. The upper threshold for tensile strength in Fig. 2A occurred despite continuing increases in tissue firmness. We interpret this as indicating that the strength of tissue slices was determined by the strength of the weakest cell, and some parenchymatous cells may have been much weaker than other cells. Furthermore, in the tensile tests some cells experienced different strains (Fig. 7), which relate to differences in cell size and orientation within the tissue. 


\section{Literature Cited}

Bourne, M.C. 1975. Methods for obtaining compression and shear coefficients of foods using cylindrical punches. J. Texture Studies 5:459-469.

Dainty, J. 1976. Water relations of plant cells. Encycl. Plant Physiol. $2 \mathrm{~A}: 12-35$

De Baerdemaeker, J., L.J. Segerlind, H. Murase, and G.E. Merva. 1978. Water potential effect on tensile and compressive failure stresses of apple and potato tissue. Amer. Soc. Agr. Eng. Paper 78-3057.

Diehl, K.C., D.D. Hamann, and K.J. Whitfield. 1979. Structural failure in selected raw fruits and vegetables. J. Texture Studies 10:371-400.

Falk, S., C.H. Hertz, and H.I. Virgin. 1958. On the relation between turgor pressure and tissue rigidity I. Physiol. Plant. 11: 802-817.

Hallett, I.C. and F.R. Harker. 1998. Microscopic investigations of fruit texture. Acta Hort. 464:411-416.

Harker, F.R. and I.C. Hallett. 1992. Physiological changes associated with development of mealiness of apple fruit during cool storage. HortScience 27:1291-1294.

Harker, F.R. and I.C. Hallett. 1994. Physiological and mechanical properties of kiwifruit tissue associated with texture change during cool storage. J. Amer. Soc. Hort. Sci. 119:987-993.

Harker, F.R., I.C. Hallett., S.H. Murray, and G. Carter. 1998. Foodmouth interactions: Towards a better understanding of fruit texture. Acta Hort. 464:461-466.

Harker, F.R., R.J. Redgwell, I.C. Hallett, S.H. Murray, and G. Carter. 1997a. Texture of fresh fruit. Hort. Rev. 20:121-224.

Harker, F.R., M.G.H. Stec, I.C. Hallett, and C.L. Bennett. 1997b. Texture of parenchymatous plant tissue: A comparison between tensile and other instrumental and sensory measurements of tissue strength and juiciness. Postharvest Biol. Technol. 11:63-72.

Harker, F.R. and P.W. Sutherland. 1993. Physiological changes associated with fruit ripening and the development of mealy texture during the storage of nectarines. Postharvest Biol. Technol. 2:269-277.

Jackman, R.L., A.G. Marangoni, and D.W. Stanley. 1992. The effects of turgor pressure on puncture and viscoelastic properties of tomato tissue. J. Texture Studies 23:491-505.

Jackman, R.L. and D.W. Stanley. 1992. Failure mechanisms of tomato pericarp tissue suggested by large and small deformation tests. J. Texture Studies 23:475-489.

Lin, T.-T. and R.E. Pitt. 1986. Rheology of apple and potato tissue as affected by cell turgor pressure. J. Texture Studies 17:291-313.

Nilsson, S.B., C.H. Hertz, and S. Falk. 1958. On the relation between turgor pressure and tissue rigidity II. Physiol. Plant. 11:818-837.

Peleg, M., L. Gomez Brito, and Y. Malevski. 1976. Compressive failure patterns of some juicy fruits. J. Food Sci. 41:1320-1324.

Pitt, R.E. 1982. Models for the rheology and statistical strength of uniformly stressed vegetative tissue. Trans. Amer. Soc. Agr. Eng. 25:1776-1784.

Pitt, R.E. and H.L. Chen. 1983. Time-dependent aspects of the strength and rheology of vegetative tissue. Trans. Amer. Soc. Agr. Eng. 26:12751280 .

Pitts, M., R. Cavalieri, and S. Drake. 1993. Apple firmness sensor update, p. 75-78. Proc. 9th Annu. Washington Tree Fruit Postharvest Conf. Wash. State Hort. Assn., Wenatchee, Wash., 17-18 Mar.

Pomper, K. W. and P. J. Breen. 1996. The effect of cell turgor on sugar uptake in strawberry fruit cortex tissue. Physiol. Plant. 96:324-332

Sakurai, N. and D.J. Nevins. 1993. Changes in physical properties and cell wall polysaccharides of tomato (Lycopersicon esculentum) pericarp tissues. Physiol. Plant. 89:681-686.

Shackel, K.A., C. Greve, J.M. Labavitch, and H. Ahmadi. 1991. Cell turgor changes associated with ripening in tomato pericarp tissue. Plant Physiol. 97:814-816.

Simon, E.W. 1977. Leakage from fruit cells in water. J. Expt. Bot. 28:1147-1152.

Steudle, E. and J. Wieneke. 1985. Changes in water relations and elastic properties of apple fruit cells during growth and development. J. Amer. Soc. Hort. Sci. 110:824-829.

Wu, N. and M.J.Pitts. 1999. Development and validation of a finite element model of an apple fruit cell. Postharvest Biol. Technol. 16:1-8. 